\title{
Effect of ultrasound treatments on functional properties and structure of millet protein concentrate
}

Nazari, Bahman ; Mohammadifar, Mohammad Amin; Shojaee-Aliabadi, Saeedeh; Feizollahi, Ehsan ; Mirmoghtadaie, Leila

\section{Published in:}

Ultrasonics Sonochemistry

Link to article, DOI:

10.1016/j.ultsonch.2017.10.002

Publication date:

2018

Document Version

Peer reviewed version

Link back to DTU Orbit

Citation (APA):

Nazari, B., Mohammadifar, M. A., Shojaee-Aliabadi, S., Feizollahi, E., \& Mirmoghtadaie, L. (2018). Effect of ultrasound treatments on functional properties and structure of millet protein concentrate. Ultrasonics

Sonochemistry, 41, 382-388. https://doi.org/10.1016/j.ultsonch.2017.10.002

\section{General rights}

Copyright and moral rights for the publications made accessible in the public portal are retained by the authors and/or other copyright owners and it is a condition of accessing publications that users recognise and abide by the legal requirements associated with these rights.

- Users may download and print one copy of any publication from the public portal for the purpose of private study or research.

- You may not further distribute the material or use it for any profit-making activity or commercial gain

- You may freely distribute the URL identifying the publication in the public portal 


\section{Accepted Manuscript}

Effect of ultrasound treatments on functional properties and structure of millet protein concentrate

Bahman Nazari, Mohammad Amin Mohammadifar, Saeedeh Shojaee-Aliabadi, Ehsan Feizollahi, Leila Mirmoghtadaie

PII: S1350-4177(17)30464-9

DOI: https://doi.org/10.1016/j.ultsonch.2017.10.002

Reference: ULTSON 3906

To appear in:

Ultrasonics Sonochemistry

Received Date:

27 November 2016

Revised Date:

2 August 2017

Accepted Date:

3 October 2017

Please cite this article as: B. Nazari, M.A. Mohammadifar, S. Shojaee-Aliabadi, E. Feizollahi, L. Mirmoghtadaie, Effect of ultrasound treatments on functional properties and structure of millet protein concentrate, Ultrasonics Sonochemistry (2017), doi: https://doi.org/10.1016/j.ultsonch.2017.10.002

This is a PDF file of an unedited manuscript that has been accepted for publication. As a service to our customers we are providing this early version of the manuscript. The manuscript will undergo copyediting, typesetting, and review of the resulting proof before it is published in its final form. Please note that during the production process errors may be discovered which could affect the content, and all legal disclaimers that apply to the journal pertain. 


\title{
Effect of ultrasound treatments on functional properties and structure of millet protein concentrate
}

Bahman Nazari ${ }^{1}$, Mohammad Amin Mohammadifar ${ }^{2}$, Saeedeh Shojaee-Aliabadi ${ }^{1}$, Ehsan Feizollahi ${ }^{1}$, Leila Mirmoghtadaie ${ }^{1 *}$

${ }^{1}$ Department of Food Science and Technology, National Nutrition and Food Technology Research Institute, Faculty of Nutrition Sciences and Food Technology, Shahid Beheshti University of Medical Sciences, Tehran, Iran

${ }^{2}$ Food Production Engineering, DTU Food, Technical University Of Denmark, Søltofts Plads227, Dk-2800 Lyngby, Denmark

\begin{abstract}
In this study, the effect of high power ultrasound (US) probe in varying intensities and times $\left(18.4,29.58\right.$, and $73.95 \mathrm{~W} / \mathrm{cm}^{2}$ for $5,12.5$ and $20 \mathrm{~min}$ respectively) on functional properties of millet protein concentrate (MPC) was investigated, and also the structural properties of best modified treatment were evaluated by FTIR, DSC, Zeta potential and SDSPAGE techniques. The results showed the solubility in all US treated MPC was significantly ( $\mathrm{e}<$ $0.05)$ higher than those of the native MPC. Foaming capacity of native MPC $(271.03 \pm 4.51 \mathrm{ml})$ was reduced after US treatments at low intensities $(82.37 \pm 5.51 \mathrm{ml})$, but increased upon US treatments at high intensities $(749.7 \pm 2 \mathrm{ml})$. In addition, EAI and ES increased after US treatments. One of the best US treatments that can improve the functional properties of MPC was $73.95 \mathrm{~W} / \mathrm{cm}^{2}$ for $12.5 \mathrm{~min}$ that resulted in reduction of molecular weight and increase nearly $36 \%$
\end{abstract}


in the negative surface charge that was confirmed by SDS-page and Zeta potential results, respectively.

Key words: high power ultrasound, Millet protein concentrate, functional properties, structural properties, modification.

\section{Introduction}

Proso millet (Panicum miliaceum L.), a comparatively short-season crop, requires little water and is able to grow at a wide range of altitudes. This cereal has considered in food production because of its advantages including high yield, affluence and low cost.[1]. In addition, proso millet has higher $(13.4 \%)$ protein content than many common cereals such as wheat $(10.5 \%)$ and rice $(6.8-7.4 \%)$ [2-4]. It contains considerable quantity of essential amino acids especially the Sulphur containing amino acids (methionine and cysteine). On the other hand, millets because of their agricultural advantages, health benefits and nutritive values have been received specific alterations as a good food source from developing countries. Health benefits such as, decreasing tumor incidence, reducing blood pressure, cholesterol absorption, preventing cardiovascular diseases and cancer, also nutritive values including provide a variety of nutrients and antioxidants needed for human health, have been reported for millets [5, 6]. They are a gluten free cereal and thus is appropriate for people with wheat/gluten allergies [7].

Proteins play different roles in food matrix that named functional properties. According to Kinsella (1976), the functional properties are "those physical and chemical properties that influence the behavior of proteins in food systems during processing, storage, cooking and consumption" and which are affected by multiple factors such as $\mathrm{pH}$, drying, heating, ionic 
strength, storage conditions, presence of reducing agents, and physical, chemical or enzymatic modifications [8].

Among the different physical methods for proteins modifications, ultrasound, which is defined as sound waves having frequency that exceeds the hearing limit of the human ear $(\sim 20$ $\mathrm{kHz}$ ), has simple, cost-effective, energy saving and environment friendly advantages [9, 10]. Generally, ultrasound power is affected by pressure, temperature, intensity, energy and velocity, that based on frequency range it can be divided into high and low energy ultrasound. Frequency between $20-100 \mathrm{kHz}$ with high intensity $\left(10-1000 \mathrm{~W} / \mathrm{cm}^{2}\right)$ used in high energy ultrasound which caused alterations in mechanical, physical, or chemical/biochemical attributes of proteins because of creation of high pressure (1000 atm) and temperature $(5000 \mathrm{~K})$ during cavitation phenomenon. In contrast, frequency between $5-10 \mathrm{MHz}$ with low intensity $\left(1 \mathrm{~W} / \mathrm{cm}^{2}\right)$ has nondestructive effects and is used to ensure high quality and safety of foods applications [10-12]. Generation of high power ultrasound could be done with sonication bath and/or transportable cheap ultrasonic immersion probes due to various goals in food manufacturing [13].

In recent years, many researchers have investigated the impact of ultrasound on functional properties of vegetable and animal protein sources specially soy proteins. In this case, the researchers showed strong effect of ultrasound treatment on foaming, solubility, emulsifying and other functional properties of these proteins [11, 14-19].

Several studies showed that emulsifying performance of egg white protein $(20 \mathrm{kHz}, 4.27$ $\mathrm{W}$, for $20 \mathrm{~min})$ and dairy proteins $\left(20 \mathrm{kHz}, 34 \mathrm{~W} / \mathrm{cm}^{2}\right.$, for $\left.2 \mathrm{~min}\right)$ improved after high power ultrasound treatment $[17,20]$. In a study conducted on animal and vegetable proteins, it was found out that solubility of pea protein concentrate and emulsifying performance of bovine 
gelatin, egg white protein and pea protein concentrate improved after ultrasound treatment (20kHz, acoustic intensity of $\sim 34 \mathrm{~W} / \mathrm{cm}^{2}$ for $2 \mathrm{~min}$ ) [17]. In another study, different ultrasound power $(200 \mathrm{~W}, 400 \mathrm{~W}, 600 \mathrm{~W})$ were used to modify emulsifying properties of Soy protein isolates (SPI). They found increase in emulsifying properties of SPI after using ultrasound. The results showed the middle power ultrasound $(400 \mathrm{~W})$ treated protein had a lower saturation surface load and a higher protein adsorption fraction that can explain its better emulsifying capability [15]. Hu et al. (2013) studied the effects of $20 \mathrm{kHz}$ (low- frequency) ultrasound at different time (15 or 30 $\min )$ and power $(200,400$ or $600 \mathrm{~W})$ on soy protein isolate structural and functional properties. They did not find significant change in the protein electrophoretic patterns. The surface hydrophobicity and protein solubility of SPI were increased with increase in both of time and power of ultrasonic treatment [18] that could lead to increase in emulsifying and foaming activity.

Due to the burgeoning world population and on the other hand enhancing cost and confined supply of animal proteins, new sources of plant proteins for use in food applications, will need to be developed [8]. The main novelty of this work is choosing millet protein concentrate as low cost and nutritious protein source. It can be show different behavior from other proteins mentioned in literature in different intensity and time. Therefore, the purpose of the present study was to examine the impact of high power ultrasound $(20 \mathrm{kHz})$ on improvement of emulsifying, foaming and solubility of millet protein concentrates to determine the possibility of using these proteins in different food applications such as emulsifier and egg replacer. In addition, FTIR, DSC, Zeta potential and SDS-Page methods was used to evaluate the relationship between physicochemical and structural properties of native and modified protein.

\section{Materials and methods}




\subsection{Materials}

Proso millet seeds were purchased from Seed \& Plant Improvement Institute, Karaj, Iran. The seeds were cleaned by hand, sieved to remove the foreign materials, and milled using a laboratory-scale hammer miller (laboratory Mill 3100, Perten co.) in the quality control lab of Ard daran Co belonging to Tak Makaron co. Alborz, Iran. The resulting millet flour were packed in polyethylene bags and stored in a refrigerator and used during one week after milling. All chemicals used in this study were of analytical grade. $\mathrm{NaOH}$ was purchased from Merck (Darmstat, Germany). gel electrophoresis protein markers Tris base, Glycine, sodium dodecyl sulphate (SDS) were obtained from Sigma Chemical Co. (Tehran, Iran). The water used in all experiments was passed through a distillation unit (A4000D, Aquatron, UK).

\subsection{Methods}

\subsubsection{Preparation of millet protein concentrates}

Millet flour was dispersed in distilled water at a flour: solvent ratio of 1:4 (w/v); the pH was adjusted to 9.5 with $1 \mathrm{~N} \mathrm{NaOH}$ to enhance protein solubilisation and it was stirred at room temperature for $60 \mathrm{~min}$. The $\mathrm{pH}$ of the supernatant obtained after centrifuging at $4000 \mathrm{~g}$ for 30 min was adjusted to 4.0 with $1 \mathrm{~N} \mathrm{HCl}$. Then it recentrifuged at $4000 \mathrm{~g}$ for $15 \mathrm{~min}$, and the protein concentrate (pellet) was recovered [21].

\subsubsection{Ultrasound treatment of millet proteins}

$50 \mathrm{ml}$ of MPC dispersions (10\% w/w) [18] were prepared by adding MPC powder into distilled water and placed in $100 \mathrm{ml}$ flat bottom conical flask. An ultrasonic processor (B03- 
Ultrasonic Processor, E-Chrom Tech Co., Ltd., Taiwan) equipped with a $3 \mathrm{~mm}$ diameter titanium sonotrode probe that provided continuous $20 \mathrm{kHz}$ wave with a total nominal output power of $100 \mathrm{~W}$, was used for sonoprocessing. The ultrasound probe was submerged in a depth of $10 \mathrm{~mm}$ in the sample and protein concentrate dispersions were sonicated for $5,12.5$ and 20 min at amplitudes of $20 \%, 60 \%$ and $100 \%$ with constant pulse durations. Sample was placed in a bottle of ice during sonication and its temperature was constant at ambient temperature (20 $30^{\circ} \mathrm{C}$ ). After ultrasound treatment, all samples were lyophilized and then stored at refrigerator temperature $\left(4^{0} \mathrm{C}\right)$ in airtight containers separately until they were analyzed. The percentage protein content (total basis) of the concentrate was 73\% using Kjeldahl method [22].

\subsubsection{Acoustic energy determination}

Actual ultrasound energy determination is necessary to ascertain the influence of ultrasound intensity in a treatment and also to be able to compare different treatments [11], since the ultrasound energy is partly lost in the form of heat when ultrasound passes though the medium [23]. The dissipated acoustic power applied to the solution was calculated with calorimetric procedure according to Margulis et al. [24]. This method involves determining the temperature increase during the first $30 \mathrm{~s}$ of the experiment. Acoustic power $(\mathrm{P})$ was then calculated using the equation:

$$
P_{a}=M C_{p}(d T / d t)
$$

Where $\mathrm{Pa}(\mathrm{W})$ is the acoustic power, $\mathrm{M}$ is the mass of ultrasound treated solution $(\mathrm{g}), \mathrm{Cp}$ is the specific heat of the medium $(\mathrm{kJ} / \mathrm{gK})$ and $\mathrm{dT} / \mathrm{dt}$ is the rate of temperature change with respect to time. Then, the acoustic power intensity, Ia $\left(\mathrm{W} / \mathrm{cm}^{2}\right)$, was calculated as follows:

$$
I_{a}=P_{a} / S_{A}
$$


Where Ia $\left(\mathrm{W} / \mathrm{cm}^{2}\right)$ is acoustic power intensity, $\mathrm{Pa}(\mathrm{W})$ is the acoustic power, SA is the surface area of the ultrasound emitting surface $\left(\mathrm{cm}^{2}\right)$.

It is expressed in watts per unit area of the emitting surface $\left(\mathrm{W} / \mathrm{cm}^{2}\right)$, or in watts per unit volume of the sonicated solution $\left(\mathrm{W} / \mathrm{cm}^{3}\right)$. Ultrasonic treatment with the $20-\mathrm{kHz}$ probe at amplitudes of 20,60 , and $100 \%$ generated power outputs of $18.4,29.58$, and $73.95 \mathrm{~W} / \mathrm{cm}^{2}$, respectively.

Samples were marked as: A (native), B1 (18.4 W/cm $\left.{ }^{2}-5 \mathrm{~min}\right), \mathrm{B} 2\left(18.4 \mathrm{~W} / \mathrm{cm}^{2}-12.5\right.$ $\mathrm{min}), \mathrm{B} 3\left(18.4 \mathrm{~W} / \mathrm{cm}^{2}-20 \mathrm{~min}\right), \mathrm{C} 1\left(29.58 \mathrm{~W} / \mathrm{cm}^{2}-5 \mathrm{~min}\right), \mathrm{C} 2\left(29.58 \mathrm{~W} / \mathrm{cm}^{2}-12.5 \mathrm{~min}\right), \mathrm{C} 3$ $\left(29.58 \mathrm{~W} / \mathrm{cm}^{2}-20 \mathrm{~min}\right), \mathrm{D} 1\left(73.95 \mathrm{~W} / \mathrm{cm}^{2}-5 \mathrm{~min}\right), \mathrm{D} 2\left(73.95 \mathrm{~W} / \mathrm{cm}^{2}-12.5 \mathrm{~min}\right)$ and D3 $(73.95$ $\left.\mathrm{W} / \mathrm{cm}^{2}-20 \mathrm{~min}\right)$.

\subsubsection{Solubility}

For this test, $1 \mathrm{~g}$ of the protein concentrate powder was dispersed in $100 \mathrm{ml}$ of distilled water $(1 \% \mathrm{w} / \mathrm{w})$ and adjusted to $\mathrm{pH} 7$ with either $1 \mathrm{~N} \mathrm{NaOH}$ or $1 \mathrm{~N} \mathrm{HCl}$. The suspension was centrifuged at $20,000 \mathrm{~g}$ for $15 \mathrm{~min}$ in $23{ }^{\circ} \mathrm{C}$ and absorbance was measured at $280 \mathrm{~nm}$ for a sample aliquot diluted 1:10 (vol/ vol) with dissociating buffer (50 mM EDTA, $8 \mathrm{M}$ urea at $\mathrm{pH} 10)$. The same procedure was performed for suspensions treated with ultrasound [25].

Solubility $(\%)=($ absorbance of the supernatant /absorbance of the dispersion before centrifugation) $\times 100$

2.2.4.2. Foaming Capacity (FC) and Foam Stability (FS) 
Foam capacity and foam stability of the millet protein concentrates at $\mathrm{pH} 7$ were determined according to the slightly modified method of Mirmoghtadaie et al. [26]. It was observed that $33.3 \mathrm{ml}$ of protein concentrate dispersion $(3 \%$, w/v in distilled water) were adjusted to $\mathrm{pH} 7$ and mixed using a magnetic stirrer for $45 \mathrm{~min}$, followed by mixing in a rotorstator homogenizer (IKA T25-Digital Ultra Turrax, Staufen, Germany) for precisely 6 min at speed 4. Afterwards, the mixture was transferred immediately into a 750-ml measuring cylinder and the foam volume was recorded. For measurement of foam stability, the total volumes of foam were read at $0,10,30,60$, and 120 min after mixing.

\subsubsection{Emulsion Activity Index (EAI) and Emulsion Stability (ES)}

The emulsion activity index (EAI) and emulsion stability (ES) were measured using the slightly modified method described by Neto et al. [27]. Ten-milliliter portions of protein solution $(1 \% \mathrm{w} / \mathrm{w})$ were homogenized with $10 \mathrm{ml}$ vegetable oil at speed 5 of a rotor-stator homogenizer (IKA T25-Digital Ultra Turrax, Staufen, Germany) for $2.5 \mathrm{~min}$ at room temperature. The emulsions were centrifuged at $1000 \mathrm{~g}$ for $5 \mathrm{~min}$. The height of the emulsified layer and that of the total contents in the tube were measured. The emulsifying activity index (EAI) was calculated as:

$E A I(\%)=($ height of emulsified layer in the tube /height of the total content in the tube) $\times 100$

Emulsion stability was determined by heating the emulsions at $80^{\circ} \mathrm{C}$ for 30 min before centrifuging at $1000 \mathrm{~g}$ for $5 \mathrm{~min}$.

$E S(\%)=($ height of emulsified layer after heating /height of the total content in the tube) $\times 100$ 


\subsubsection{Physical and structural properties}

\subsubsection{Sodium Dodecyl Sulfate Polyacrylamide Gel Electrophoresis (SDS-PAGE)}

Electrophoresis was conducted using method descried by Sambrook et al. [28] using 12\% separating gel and 5\% stacking gel. Freeze dried MPC samples $(0.001 \mathrm{~g}$ in 200 microliter of reducing SDS loading buffer containing $50 \mathrm{mM}$ tris-HCL pH=6.8, $100 \mathrm{mM}$ dithiothreitol, 10\% glycerin, $2 \% \mathrm{SDS}$, and $0.1 \%$ bromophenol blue) heated for $10 \mathrm{~min}$ at $90^{\circ} \mathrm{C}$ to denature all the proteins. Then, the samples were cooled as soon as possible in refrigerator $\left(4^{\circ} \mathrm{C}\right)$ and its aliquots (5 microliter) loaded into the wells containing tris-acrylamide gel. Gel electrophoresis was initially run at $80 \mathrm{~V}$ and when the samples were within the separation gradient gel, voltage was increased to $120 \mathrm{~V}$. then the gels were stained using coomassie blue R-250, and de-stained overnight.

\subsubsection{Zeta potential $(\zeta)$}

The zeta potential of native or ultrasonicated millet protein concentrate was measured using a Zetasizer Nano ZS (Malver Instrument Ltd., Malvern, Worcestershire, UK). Lyophilized millet protein concentrates were diluted to $2 \mathrm{mg} / \mathrm{mL}$ with deionized water and filtered through a $0.45 \mu \mathrm{HA}$ Millipore membrane prior to analysis at room temperature $\left(25^{0} \mathrm{C}\right)$.

\subsubsection{Fourier-Transform Infrared Spectra (FTIR)}

The FTIR measurements were performed for structural characterization of microparticles. The dry samples were mixed with $\mathrm{KBr}$ and pressed to form pellets. FT-IR spectra of samples 
were obtained from wave number $400-4000 \mathrm{~cm}^{-1}$ using a FT-IR spectrophotometer (Perkin Elmer Spectrum RX I, USA). For each spectrum, 16 scans at a resolution of $4 \mathrm{~cm}^{-1}$ were obtained.

\subsubsection{Differential Scanning Calorimetry (DSC)}

Differential scanning calorimetry was used to determine the onset ( $\left.\mathrm{T}_{\text {onset }}\right)$ temperature, peak temperature $\left(T_{p}\right)$, and end set temperature $\left(T_{\text {end }}\right)$ for sonicated and untreated protein dispersions.

The DSC thermograms of the samples were registered using a Shimadzu DSC-60 differential scanning calorimeter (Shimadzu, Kyoto, Japan). The instrument was calibrated with indium $\left(156.6^{\circ} \mathrm{C}\right)$, lead $\left(327.5^{\circ} \mathrm{C}\right)$ and zinc $\left(419.6^{\circ} \mathrm{C}\right)$. Samples $(2.88 \mathrm{mg})$ were hermetically sealed in aluminum pans and heated from 25 to $135^{\circ} \mathrm{C}$ at a scanning rate of $10^{\circ} \mathrm{C} / \mathrm{min}$ under a nitrogen atmosphere. An empty aluminum pan of equal weight was used as the reference.

\subsection{Statistical analysis}

Analyses were done in triplicate. The data were statistically analyzed with SPSS vs.21 software. One-way analysis of variance (ANOVA) with a 95\% confidence interval was used to assess the significance of the results obtained. The ANOVA data with $\mathrm{P}<0.05$ were considered as statistically significant.

\section{Results and Discussion}


3.1. Comparison of the functional properties of native and sonicated millet protein concentrate (MPC)

\subsubsection{Solubility}

As can be seen in Figure 1, solubility of MPC after ultrasound treatment in all of the used times and amplitudes were significantly higher than the untreated sample with the highest solubility in $73.95 \mathrm{~W} / \mathrm{cm}^{2}$ intensity for $12.5 \mathrm{~min}$. The results indicated that increase in US time from 5 to $20 \mathrm{~min}$ at $18.4 \mathrm{~W} / \mathrm{cm}^{2}$ intensity did not show significant improvement in solubility of MPC. On the other hand, increase in level of US time from 12.5 to $20 \mathrm{~min}$ at $73.95 \mathrm{~W} / \mathrm{cm}^{2}$ intensity reduced it. In various studies Chen et al. 2011 [15], Jambrak et al. 2009 [29] and Karki et al. (2009) [19] showed improvement in protein solubility of protein after increase in intensity and time of ultrasound treatment.

The improvement in solubility of MPC after ultrasound treatment could be attributed to several factors such as exposure of inside hydrophilic groups of amino acids toward water that is confirmed by breakage in internal interactions and conformational change of MPC showed with positional change in amid II region of FTIR results (Fig 3).

Jambrak et al. [29] also pointed out that hydrogen and hydrophobic bond breakage by cavitation phenomenon causes decrease in protein molecular weight and subsequently increase in interaction between protein and water molecule and so larger surface of protein concealed by water molecule. This is predictable due to SDS- page results (Fig 2) that confirmed alteration and decrease in molecular weight. On the other hand intramolecular bonds breakage confirmed by decrease in $\triangle \mathrm{H}$ of MPC after US treatment showed with DSC results (Table 3). Arzeni et al. (2011) also stated increase in protein solubility after ultrasonication because of reduce in particle 
size of SPI, which can increase protein and water interactions [11]. On the other hand, Hu et al. (2013) [18] did not find any change in SDS- Page result of ultrasound treated SPI samples. However, they correlated increase in treated sample solubility to the probable formation of soluble protein aggregates from insoluble protein. In another part of their study, different reagent was used to show which type of protein bonds is most affected by ultrasound. They have concluded that ultrasound could disrupt hydrogen bonds and hydrophobic interactions that have main role in intermolecular behavior of proteins. Ultrasound cavitations that lead to turbulent flow and high shear force can create large interfacial area between air and water that may disturb hydrogen bond and hydrophobic interaction around the protein molecules [18]. Therefore, it can change the functional properties of treated protein.

Furthermore, in confirming the zeta potential results (Table 3), it was shown that the US treatment increased the negative surface charge on MPC, thereby leading to increase in the expansion of protein aggregates and also prevent of further aggregation, so modified the protein dispersions stability [30].

The small but significant decrease in the solubility of MPC after using the highest intensity and time $\left(73.95 \mathrm{~W} / \mathrm{cm}^{2}\right.$ for $\left.20 \mathrm{~min}\right)$, may be due to creation of small aggregates upon US treatment, which has also been observed by Arzeni et al.[11]. They reported that high intensity ultrasound $(20 \mathrm{kHz}, 4.27 \pm 0.71 \mathrm{~W}$ for $20 \mathrm{~min})$ could create hydrophobic interactions and subsequently form small aggregations. Sonochemical effects (water sonolysis) of sonication on food proteins at high ultrasound frequency may be induced cross-linkage of protein molecules during ultrasound treatment of millet proteins with high intensity (D3 treatment) in aqueous medium [31]. Hu et al, also at their study on sonicated soy protein isolate $(20 \mathrm{kHz}, 131-138$ 
$\mathrm{W} / \mathrm{cm}^{2}$, for $15-30 \mathrm{~min}$ ) that is very stronger than our used intensity, pointed out that there are some other type of covalent bonds that may be were formed upon ultrasound treatment [18].

Figure 1

\subsubsection{Foaming Capacity (FC) and Foam Stability (FS)}

As suggested in Table 1, FC of MPC in lower intensities and times $\left(\mathrm{B}_{1}, \mathrm{~B}_{2}, \mathrm{~B}_{3}, \mathrm{C}_{1}, \mathrm{C}_{2}\right)$ was significantly lower than the untreated sample in which the minimum $\mathrm{FC}$ was observed for $\mathrm{C}_{1}$ treatment; however the FC of MPC increased significantly as the time of ultrasound treatment in high intensities $\left(C_{3}, D_{1}, D_{2}, D_{3}\right)$ was prolonged. The decrease in FC and no improvement in FS at low intensities and times of US treatment (Table 1) were observed.

Improvement in FC by increase in amplitude of US treatment could be attributed to increase in exposure of hydrophobic regions due to unfolding of MPC molecules during US treatment that confirmed by FTIR data (Fig 3) that showed change in structure of MPC and breakage in internal interactions. Chen et al. (2011) also showed increase in surface hydrophobicity of SPI after ultrasound treatment. Another study that used different time and intensity showed increase in surface hydrophobicity of sonicated protein with increase in ultrasonic time (15 to $30 \mathrm{~min}$ ) and intensity $(200,400$ or $600 \mathrm{~W}$ that could be due to exposure of buried hydrophobic region from the interior of the molecules by cavitation phenomenon to the surface of SPI molecule. The greater solubility along with higher surface hydrophobicity of sonicated Soy protein isolate may be due to smaller particle size and decrease in intermolecular interactions of SPI dispersions [18]. 
Also, decrease in $\Delta \mathrm{H}$ showed by DSC data (Table 3) confirmed the intramolecular destruction of MPC upon US treatment. As well as the US created shearing force caused reduction in protein molecule size and then accelerated the movement and penetration of the protein molecules in the air/water interface [32, 33]. This mechanism can stablished by SDSpage results (Fig 2) that showed decrease in molecular weight of MPC and also increase in MPC solubility results after US treatment.

According to the karki et al.[19] low intensity US treatment might have changed the structure of the protein in a manner that led to little surface activity by preventing the protein capability to unfolding (create film) at the air/water interface.

Table 1

3.1.3. Emulsion Activity Index (EAI) and Emulsion Stability (ES)

To detect EAI and ES of protein concentrate, a protein - oil emulsion was prepared by a homogenizer. Table 2 show that there is a significant improvement in EAI and ES of MPC after US treatment in which the maximum EAI and ES were observed for $\mathrm{D}_{2}$ treatment $(56.25 \pm 1.25$ and $48.13 \pm 4.49 \%$ respectively).

With increase in US treatment time from 5 to $12.5 \mathrm{~min}$ at $18.4 \mathrm{~W} / \mathrm{cm}^{2}$ intensity, the EAI of MPC did not show significant improvement, but an increase from 12.5 to 20 min led to significant improvement. However, increase in US time from 12.5 to $20 \mathrm{~min}$ at $73.95 \mathrm{~W} / \mathrm{cm}^{2}$ intensity caused significant decrease in the EAI of MPC. The data indicated that US intensity 
was more effective than US time in ESI improvement of MPC. However, in $73.95 \mathrm{~W} / \mathrm{cm}^{2}$ intensity, the ES at 12.5 min treatment was significantly higher than that at $20 \mathrm{~min}$.

Similar reports about improvement in emulsifying properties of proteins are available for milk protein concentrate $(20 \mathrm{kHz}$ probe, $12.5 \mathrm{~W}$, for 1,2 and $5 \mathrm{~min})$, wheat gluten $(20 \mathrm{kHz}$ probe, $10.8,14.4$ and $18.0 \mathrm{~W} / \mathrm{cm}^{2}$, for $\left.10 \mathrm{~min}\right)$, soy protein isolate and concentrate $(20 \mathrm{kHz}$ probe, 45 $\mathrm{Wcm}^{-2}$, for $\left.30 \mathrm{~min}\right)$ and egg white proteins $(20 \mathrm{kHz}, 4.27 \mathrm{~W}$, for $20 \mathrm{~min})$ that are treated by high power ultrasound $[16,20,33,34]$.

This improvement can be explained by breakages in the structure of MPC that showed with decrease in molecular weight by the SDS-PAGE results (Fig 2). It also have been showed with increase in number of peaks at native MPC to two wave number, that described decrease in average particle size of MPC by the FTIR results (Fig 3), because of the US effect created disturbed flow. These phenomena subsequently lead to increase in proteins tendency to adsorption at the oil and water interfaces that is aligned with solubility outcomes (Fig 1).

Since the correlation between emulsifying capacity and emulsion stability of proteins with surface hydrophobicity has been proven well [35], exposure of the inner hydrophobic groups at the proteins surfaces upon US treatment, (confirmed with decrease in intramolecular interaction of MPC and exposure the buried hydrophobic groups by the FTIR results (Fig 3)), leads to higher emulsifying properties.

Our results are in agreement with those of Osullivon et al.[17], who observed a significant improvement in the stability of the emulsions treated by ultrasound $(20 \mathrm{kHz}, \sim 34 \mathrm{~W}$ $\mathrm{cm}-2$ for $2 \mathrm{~min}$ ). Also improvement in the ES may be due to better favorable orientation of proteins, under the effect of ultrasound treatment and adsorption of oil droplets in emulsions [36] 
that confirmed by FTIR results since showed alteration in the secondary structure of MPC by positional change in amid II region (Fig 3).

Table 2

3.2. Effect of sonication on the structural properties of selected millet protein concentrate

Since the most of the investigated functional properties including the solubility, emulsifying and foaming properties of MPC were highest after ultrasonication in D2 treatment that may be due to the greatest change in its structure, this treatment was selected as the best one for comparison of structural properties of US treated and native millet protein concentrate.

\subsubsection{Sodium Dodecyl Sulfate Polyacrylamide Gel Electrophoresis (SDS-PAGE)}

Figure 2 presented SDS-page of the ladder, native and US treated (D2) MPC. Comparison of the electrophoretic patterns of the native and US treated MPC showed major changes especially in the 40 and $50 \mathrm{kDa}$ bonds after treatment in $73.95 \mathrm{~W} / \mathrm{cm}^{2}$ intensity for 12.5 min. Our results support those of jambrak et al.(2010) that showed the effect of US treatment (20 $\mathrm{kHz}, 73.95 \mathrm{~W} / \mathrm{cm}^{2}$ for $15 \mathrm{~min}$ ) on the molecular weight of a-lactalbumin. Alteration observed in the molecular structure of MPC is related to creation of disturbed flow with high shear, in the liquid surroundings protein, after US treatment [32].

However, the results are in disagreement with those of Jiang et al. [30] study, in that, they found no change in molecular weight of native black bean protein isolates after ultrasound treatment $\left(20 \mathrm{kHz}, 72-120 \mathrm{~W} / \mathrm{cm}^{2}\right.$ for 12 and $\left.24 \mathrm{~min}\right)$. This difference may be due to application 
of stronger ultrasound intensity $\left(120 \mathrm{~W} / \mathrm{cm}^{2}\right.$ ) than our study (maximum intensity $73.95 \mathrm{~W} / \mathrm{cm}^{2}$ ) caused noncovalent interactions such as electrostatic and hydrophobic interactions. Formation of hydrophobic interactions subsequently creates small aggregations and finally increases the molecular weight of protein again.

Figure 2

\subsubsection{Zeta potential $(\zeta)$}

Usually, more presence of amino acids with negative charge than amino acids with positive charge in a protein surface resulted in negative $\mathrm{Z}$ potential of the protein and contrariwise.

The results (Table 3) indicated that the negative $\zeta$ potential of native MPC was enhanced upon US treatment (D2) from -32.9 to $-42.2(\mathrm{mV})$, which demonstrated that US treated MPC contained more amino acids with negative charge in the protein surface than native MPC.

This increase in overall surface charge of MPC was due to increase in exposure of charge residues in the surface of protein molecules to solvent molecules. This phenomenon caused by structural change upon US treatment that was confirmed by DSC result (Table 3) that showed decrease in enthalpy change due to US treatment [30].

Jiang et al. [30] and Gulseren et al. [37] showed ultrasound treatment (20kHz, 96-104 $\mathrm{W} / \mathrm{cm}^{2}$, for $12-24 \mathrm{~min}$ and $20 \mathrm{kHz}, 2073.95 \mathrm{~W} / \mathrm{cm}^{2}$, for $15-30-45 \mathrm{~min}$ respectively), can increase 
the negative zeta potential of black bean protein and bovine serum albumin solutions, maximum approximately 75 and $35 \%$, respectively.

\subsubsection{Fourier-Transform Infrared Spectra (FTIR)}

Alteration of the protein structure was investigated mostly by analyzing the changes of peak position in amid regions (amid I, II, III). Spectral regions of $1700-1600 \mathrm{~cm}^{-1}$, which attributed to amide $\mathrm{I}$ band is due to the $\mathrm{C}-\mathrm{O}$ stretch vibrations of protein linkages and it is most sensitive to alteration in the protein secondary structures compared to amid II region (1480 $1575 \mathrm{~cm}^{-1}$ ). Amid III bands occur in the wavenumber range of from 1200-1400 $\mathrm{cm}^{-1}$ [38].

FT-IR has been used to study the change in the structure and functional groups of MPC upon US treatment. Comparison of FT-IR spectra presented in Figure 3 revealed differences in the structural and chemical composition of native and US treated MPC. Although the spectrum in $1464.8 \mathrm{~cm}^{-1}$ between the native and US treated MPC was similar, overall the observed absorption bands varied after US treated MPC. As seen at Fig 3, the amid III bands at native MPC were located at $1243.15 \mathrm{~cm}^{-1}$, suggesting that B-sheets are the predominant secondary structures.

One interesting finding was that the US treated MPC increased the number of peaks at native MPC in $723.34 \mathrm{~cm}^{-1}$ wave number into two wave numbers, at $722.25 \mathrm{~cm}^{-1}$ and $872.89 \mathrm{~cm}^{-}$

1. This may be defined by the fact that the average particle size was reduced by sonication [12].

The peak spectra of amid II (1530-1550 $\left.\mathrm{cm}^{-1}\right)$ after US treatment shifted from 1546.19 $\mathrm{cm}^{-1}$ to $1539.26 \mathrm{~cm}^{-1}$. This decrease in wave number may be due to turning the portion of 
random coil into $\beta$-sheet in MPC. Alteration in the secondary structure of MPC was revealed by positional change in amid II region. This result is in agreement with the results of Li et al.[39]. According to them in their study, the quantity of intramolecular hydrogen bond decreased and the negative charge increased by turning the amid group into carboxyl and thus subsequently caused enhancement of electrostatic repulsion as seen at our Zeta potential results (Table 3). Generally, US treatment led to breakage in internal interactions of MPC.

The observed peak in native MPC spectra at $3286.71 \mathrm{~cm}^{-1}$ which was related to the N-H stretching vibration, shifted to $3418.39 \mathrm{~cm}^{-1}$ in the spectra of sonicated MPC [40]. These increase in wave number according to the fact that frequency of stretching vibration reduced because of hydrogen bond formation [41]. It can be due to hydrogen bond disruption in sonication by means of increase in net negative charge that was aligned with Zeta potential result (Table 3) that showed $36 \%$ enhancement in the net negative surface charge of native MPC upon US treatment.

Figure 3

\subsubsection{Differential Scanning Calorimetry (DSC)}

Resistance of protein against aggregation during heating is measured as its thermal stability. A quick and easy technique for studying protein thermal stability is DSC which supplies $\mathrm{T}_{\mathrm{d}}$ and $\Delta \mathrm{H}$ information about samples. $\mathrm{T}_{\mathrm{d}}$ reflects the temperature at which protein denaturation occurs and $\Delta \mathrm{H}$ shows the quantity of heat demanded to induce protein denaturation [42]. It is well known that the situation of ordered conformation of proteins is reflected by the 
enthalpy change $(\Delta \mathrm{H})$. The DSC information is beneficial for heat processing strategies of food [43].

Data from DSC measurements for native and US treated (D2) MPC heated from 25 to $135^{\circ} \mathrm{C}$ at $10^{\circ} \mathrm{C} / \mathrm{min}$ are given in Table 3 . Every two samples showed a single broad endothermic with a $\mathrm{T}$ peak (denaturation temperature) at $60.97^{\circ} \mathrm{C}$ and $59.56^{\circ} \mathrm{C}$ about native and US treated MPC respectively. Variation in denaturation temperature between native and ultrasonicated sample was not significant. $\mathrm{T}$ peak had been related to the protein structure and conformations and also creating amino acid composition [44], so a little change in Td (Table 3), was due to conformational alteration in MPC upon US treatment. This conformational change was proved before in study on effect of ultrasonification on secondary structure of Soy protein isolate using Circular dichroism (CD) spectra. The results showed greater changes in the secondary structure of SPI at higher time and power. They suggested decrease in a-helix and random coil structures of soy protein isolate after ultrasonic treatment at lower power that was increased after treatment at higher power[18].

The enthalpy $(\Delta \mathrm{H})$ of native and US treated MPC was 31.08 and $23.92 \mathrm{j} / \mathrm{g}$ respectively. This decrease in $\Delta \mathrm{H}$ by US treatment indicate less energy was required to unfolding of ultrasonicated MPC sample because of destruction of intramolecular bonds of MPC in result of shear forces created cavitation bubbles. This result is aligned with FTIR results (Fig 3) showed increase in peak number and also Zeta potential outcome (Table 3) confirmed increase in net negative charge due to breakage in intramolecular bonds and exposure of buried negative charges after US treatment, which have also been shown in the previous studies $[19,37,45]$. 
Table 3

\section{Conclusions}

In this study, MPC was affected by the high power US probe $(20 \mathrm{kHz})$ in varying intensities and times $\left(18.4,29.58\right.$, and $73.95 \mathrm{~W} / \mathrm{cm}^{2}$ for $5,12.5$ and $\left.20 \mathrm{~min}\right)$ and the impact of this process on the functional and structural properties of MPC was investigated.

US treatments significantly $(\mathrm{P}<0.05)$ increased the solubility of the native MPC $(65.8 \pm 0.6 \%)$ at all sonicated times with maximum solubility that recorded at D2 treatment $(96.9 \pm 0.82 \%)$. FC of MPC was also significantly affected by the US treatment. Increase in sonicated time up to $12.5 \mathrm{~min}$ at $73.95 \mathrm{~W} / \mathrm{cm}^{2}$ significantly increase the FC of native MPC $(271.03 \pm 4.51 \mathrm{ml})$, but more increase at this reduced it significantly. Minimal improvements were observed in the FS of All sonicated MPC compared to native MPC. Sonicated time for $12.5 \mathrm{~min}$ at $73.95 \mathrm{~W} / \mathrm{cm}^{2}$ affected the EAI and ES of the native MPC more markedly than other treatments, may be attributed to more increase in proteins tendency to adsorption at the oil and water interfaces after US treatment at this treatment. Generally, the major effect on these functional properties was observed for $12.5 \mathrm{~min}$ at $73.95 \mathrm{~W} / \mathrm{cm}^{2}(\mathrm{D} 2)$. The main reason for this improvement was attributed to the disturbed flow produced by ultrasound cavitation. However, increase in the treatment time to $20 \mathrm{~min}$ in intensity of $73.95 \mathrm{~W} / \mathrm{cm}^{2}$ caused formation of small aggregate and subsequently showed a decline in these functional properties.

DSC data analysis indicated that enthalpy $(\Delta \mathrm{H})$ of US treated MPC compared to native MPC, declined. FTIR and SDS-PAGE analysis showed changes in the secondary structure and molecular weight of MPC respectively, attributed to shearing forces created by cavitation 
phenomenon. Also this phenomenon caused increase in exposure of more amino acids with negative charge in surface of US treated MPC, that demonstrated by Zetasizer data.

So, US treatment can be used as green technology to improve MPC functional properties and make modified protein as a potential ingredient in different food applications including bread, cake, ice cream and confectionary products. However further studies are needed to discern its functional properties in real food systems.

\section{References}

[1] Y.I. Cho, J.W. Chung, G.A. Lee, K.H. Ma, A. Dixit, J.G. Gwag, Y.J. Park, Development and characterization of twenty-five new polymorphic microsatellite markers in proso millet (Panicum miliaceum L.), Genes Genomics, 32 (2010) 267-273.

[2] K. Kulp, J. G, P. Jr, Handbook of Cereal Science and Technology, Revised and Expanded, Marcel Dekker, Inc., 2000.

[3] M.N. Sainam, V.S. Gupta, V.K. Mishra, A.H. Lachkeip, R. Ranjekar, D.T.N. Pillay, Effect of chemical modification on some structural and functional properties of pennisetin, a major seed storage protein from pearl millet Phytockmisrry, 34 (1993) 919-925.

[4] S. Kasaoka, A. Oh-hashi, T. Morita, S. Kiriyama, Nutritional characterization of millet protein concentrates produced by a heat-stable $\alpha$-amylase digestion, Nutr. Res., 19 (1999) 899-910.

[5] N. Nishizawa, D. Sato, Y. Ito, T. Nagasawa, Y. Hatakeyama, M.-R. Choi, Y.-Y. Choi, Y.M. Wei, Effects of dietary protein of proso millet on liver injury induced by D-galactosamine in rats, Bioscience, biotechnology, and biochemistry, 66 (2002) 92-96.

[6] A.S. Saleh, Q. Zhang, J. Chen, Q. Shen, Millet grains: nutritional quality, processing, and potential health benefits, Comprehensive reviews in food science and food safety, 12 (2013) 281-295. 
[7] I. Amadou, M.E. Gounga, L. Guo-Wei, Millets Nutritional composition, some health benefits and processing-A, Emir. J. Food Agric, 25 (2013) 501-508.

[8] J.E. Kinsella, N. Melachouris, Functional properties of proteins in foods: a survey, Critical Reviews in Food Science \& Nutrition, 7 (1976) 219-280.

[9] D. Knorr, A. Froehling, H. Jaeger, K. Reineke, O. Schlueter, K. Schoessler, Emerging technologies in food processing, Annual review of food science and technology, 2 (2011) 203-235.

[10] O. Higuera-Barraza, C. Del Toro-Sanchez, S. Ruiz-Cruz, E. Márquez-Ríos, Effects of high-energy ultrasound on the functional properties of proteins, Ultrasonics sonochemistry, 31 (2016) 558-562.

[11] C. Arzeni, K. Martínez, P. Zema, A. Arias, O.E. Pérez, A.M.R. Pilosof, Comparative study of high intensity ultrasound effects on food proteins functionality, Journal of Food Engineering, 108 (2012) 463472.

[12] H. Hu, E.C. Li-Chan, L. Wan, M. Tian, S. Pan, The effect of high intensity ultrasonic pre-treatment on the properties of soybean protein isolate gel induced by calcium sulfate, Food Hydrocolloids, 32 (2013) 303-311.

[13] T. Awad, H. Moharram, O. Shaltout, D. Asker, M. Youssef, Applications of ultrasound in analysis, processing and quality control of food: A review, Food Research International, 48 (2012) 410-427.

[14] R. Morales, K. D. Martínez, V.M.P. Ruiz-Henestrosa, A. M.R. Pilosof, Modification of foaming properties of soy protein isolate by high ultrasound intensity: Particle size effect, Ultrasonics Sonochemistry, 26 (2015) 48-55.

[15] L. Chen, J.S. Chen, L. Yu, K.G. Wu, X.L. Liu, X.H. Chai, Modifications of Soy Protein Isolates Using Ultrasound Treatment for Improved Emulsifying Properties, in: Advanced Materials Research, Trans Tech Publ, 2012, pp. 944-948.

[16] A.R. Jambrak, V. Lelas, T.J. Mason, G. Krešić, M. Badanjak, Physical properties of ultrasound treated soy proteins, Journal of Food Engineering, 93 (2009) 386-393. 
[17] J. O'Sullivan, B. Murray, C. Flynn, I. Norton, The effect of ultrasound treatment on the structural, physical and emulsifying properties of animal and vegetable proteins, Food Hydrocolloids, (2015).

[18] H. Hu, J. Wu, E.C. Li-Chan, L. Zhu, F. Zhang, X. Xu, G. Fan, L. Wang, X. Huang, S. Pan, Effects of ultrasound on structural and physical properties of soy protein isolate (SPI) dispersions, Food Hydrocolloids, 30 (2013) 647-655.

[19] B. Karki, B.P. Lamsal, D. Grewell, A.L. Pometto, J. van Leeuwen, S.K. Khanal, S. Jung, Functional Properties of Soy Protein Isolates Produced from Ultrasonicated Defatted Soy Flakes, Journal of the American Oil Chemists' Society, 86 (2009) 1021-1028.

[20] C. Arzeni, O.E. Pérez, A.M. Pilosof, Functionality of egg white proteins as affected by high intensity ultrasound, Food Hydrocolloids, 29 (2012) 308-316.

[21] L. Mirmoghtadaie, M. Kadivar, M. Shahedi, Effect of Modified Oat Starch and Protein on Batter Properties and Quality of Cake, cereal chemistry, 86 (2009) 685-691.

[22] AOAC, Association of Official Analytical Chemists, in: Official methods of analysis, 14th ed, Washington, DC, 1985.

[23] L. Thompson, L. Doraiswamy, Sonochemistry: science and engineering, Industrial \& Engineering Chemistry Research, 38 (1999) 1215-1249.

[24] M. Margulis, I. Margulis, Calorimetric method for measurement of acoustic power absorbed in a volume of a liquid, Ultrasonics Sonochemistry, 10 (2003) 343-345.

[25] M. Britten, H.J. Giroux, V. Gaudin, Effect of $\mathrm{pH}$ during heat processing of partially hydrolyzed whey protein, Journal of dairy science, 77 (1994) 676-684.

[26] L. Mirmoghtadaie, M. Kadivar, M. Shahedi, Effects of succinylation and deamidation on functional properties of oat protein isolate, Food Chemistry, 114 (2009) 127-131.

[27] V. Neto, N. Narain, J. Silva, P. Bora, Functional properties of raw and heat processed cashew nut (Anacardium occidentale, L.) kernel protein isolates, Food/Nahrung, 45 (2001) 258-262. 
[28] J. Sambrook, D.W. Russell, Molecular cloning. A laboratory manual. Third, Cold pring Harbor Laboratory Press, New York, (2001).

[29] A.R. Jambrak, T.J. Mason, V. Lelas, Z. Herceg, I.L. Herceg, Effect of ultrasound treatment on solubility and foaming properties of whey protein suspensions, Journal of Food Engineering, 86 (2008) 281-287.

[30] L. Jiang, J. Wang, Y. Li, Z. Wang, J. Liang, R. Wang, Y. Chen, W. Ma, B. Qi, M. Zhang, Effects of ultrasound on the structure and physical properties of black bean protein isolates, Food Research International, 62 (2014) 595-601.

[31] A.C. Soria, M. Villamiel, Effect of ultrasound on the technological properties and bioactivity of food: a review, Trends in Food Science \& Technology, 21 (2010) 323-331.

[32] A.R. Jambrak, V. Lelas, T.J. Mason, G. Krešic, Ultrasonic effect on physicochemical and functional properties of a-lactalbumin, Food Science and Technology, 43 (2010) 254-262.

[33] Zhang H, Claver I.P, Zhu K.X, Z. H., The Effect of Ultrasound on the Functional Properties of Wheat Gluten, Molecules, 16 (2011) 4231-4240.

[34] S. Yanjun, C. Jianhang, Z. Shuwen, L. Hongjuan, L. Jing, L. Lu, H. Uluko, S. Yanling, C. Wenming, G. Wupeng, Effect of power ultrasound pre-treatment on the physical and functional properties of reconstituted milk protein concentrate, Journal of Food Engineering, 124 (2014) 11-18.

[35] S. Nakai, Structure-function relationships of food proteins: with an emphasis on the importance of protein hydrophobicity, Journal of agricultural and food chemistry, 31 (1983) 676-683.

[36] E. Dickinson, V.B. Galazka, Emulsion stabilization by ionic and covalent complexes of $\beta$ lactoglobulin with polysaccharides, Food Hydrocolloids, 5 (1991) 281-296.

[37] İ. Gülseren, D. Güzey, B.D. Bruce, J. Weiss, Structural and functional changes in ultrasonicated bovine serum albumin solutions, Ultrasonics Sonochemistry, 14 (2007) 173-183.

[38] G. Zandomeneghi, M.R. Krebs, M.G. McCammon, M. Fändrich, FTIR reveals structural differences between native $\beta$-sheet proteins and amyloid fibrils, Protein Science, 13 (2004) 3314-3321. 
[39] S. Li, X. Yang, Y. Zhang, H. Ma, W. Qu, X. Ye, R. Muatasim, A.O. Oladejo, Enzymolysis kinetics and structural characteristics of rice protein with energy-gathered ultrasound and ultrasound assisted alkali pretreatments, Ultrasonics Sonochemistry, 31 (2016) 85-92.

[40] J. Kong, S. Yu, Fourier transform infrared spectroscopic analysis of protein secondary structures, Acta biochimica et biophysica Sinica, 39 (2007) 549-559.

[41] A. Barth, Infrared spectroscopy of proteins, Biochimica et Biophysica Acta (BBA)-Bioenergetics, 1767 (2007) 1073-1101.

[42] P. Kaushik, K. Dowling, S. McKnight, C.J. Barrow, B. Wang, B. Adhikari, Preparation, characterization and functional properties of flax seed protein isolate, Food chemistry, 197 (2016) 212220.

[43] K.S. Kumar, K. Ganesan, K. Selvaraj, P.S. Rao, Studies on the functional properties of protein concentrate of Kappaphycus alvarezii (Doty) Doty-An edible seaweed, Food chemistry, 153 (2014) 353360.

[44] K. Shevkani, N. Singh, A. Kaur, J.C. Rana, Structural and functional characterization of kidney bean and field pea protein isolates: A comparative study, Food Hydrocolloids, 43 (2015) 679-689.

[45] J. Chandrapala, B. Zisu, M. Palmer, S. Kentish, M. Ashokkumar, Effects of ultrasound on the thermal and structural characteristics of proteins in reconstituted whey protein concentrate, Ultrasonics Sonochemistry, 18 (2011) 951-957. 
Table 1. Effect of US treatments on foam capacity (FC) and foam stability (FS) of MPC

\begin{tabular}{|c|c|c|c|c|}
\hline \multirow[t]{2}{*}{ sample } & \multirow[t]{2}{*}{$\mathrm{FC}(\mathrm{ml})$} & \multicolumn{3}{|c|}{ FS (min) } \\
\hline & & 0 & 10 & 30 \\
\hline $\mathrm{A}$ & $271.03 \pm 4.5^{\mathrm{e}}$ & $271.03 \pm 4.5^{\mathrm{e}}$ & $4.37 \pm 1.52^{\mathrm{e}}$ & - \\
\hline B1 & $114.70 \pm 3^{\mathrm{i}}$ & $114.70 \pm 3^{\mathrm{i}}$ & $19.03 \pm$ & - \\
\hline B2 & $193.70 \pm 4^{\mathrm{f}}$ & $193.70 \pm 4^{\mathrm{f}}$ & $10.70 \pm 3^{d}$ & - \\
\hline B3 & $148.37 \pm 6.65^{\mathrm{g}}$ & $148.37 \pm 6.65^{\mathrm{g}}$ & $18.37 \pm 2.08^{c}$ & - \\
\hline $\mathrm{C} 1$ & $82.37 \pm 5.5^{\mathrm{j}}$ & $82.37 \pm 5.5^{j}$ & $0.56 \pm 0.98^{\mathrm{d}}$ & - \\
\hline $\mathrm{C} 2$ & $127.70 \pm 2^{\mathrm{h}}$ & $127.70 \pm 2^{\mathrm{h}}$ & $2.57 \pm 4.44^{\mathrm{e}}$ & - \\
\hline $\mathrm{C} 3$ & $435.37 \pm 2.52^{c}$ & $435.37 \pm 2.52^{c}$ & $10.70 \pm 1^{\mathrm{e}}$ & - \\
\hline D1 & $346.37 \pm 2$ & $346.37 \pm 2.08^{\mathrm{d}}$ & $14.70 \pm 03^{\mathrm{cd}}$ & - \\
\hline D2 & $749.70 \pm 2^{\mathrm{a}}$ & $749.70 \pm 2^{\mathrm{a}}$ & $95.70 \pm 6.56^{\mathrm{a}}$ & $14.37 \pm 0.58^{a}$ \\
\hline D3 & $6.03 \pm 3.51^{b}$ & $716.03 \pm 3.51^{b}$ & $25.70 \pm 3^{\mathrm{b}}$ & - \\
\hline
\end{tabular}

Results are mean values of triplicate determinations, \pm standard deviation. Means in each column followed by different letters are significantly different $(\mathrm{P}<0.05)$ : small letters show statistical differences for data in column, respectively. 
Table 2. Effect of US treatments on emulsion activity index (EAI) and emulsion stability (ES) of MPC

\begin{tabular}{lll}
\hline sample & EAI $(\%)$ & ES (\%) \\
\hline A & $27.92 \pm 1.9^{\mathrm{g}}$ & $10.97 \pm 1.5^{\mathrm{e}}$ \\
B1 & $32.92 \pm 2.6^{\mathrm{f}}$ & $20.75 \pm 1.85^{\mathrm{d}}$ \\
B2 & $33.75 \pm 2.5^{\mathrm{f}}$ & $20.03 \pm 0.64^{\mathrm{c}}$ \\
B3 & $39.17 \pm 0.75^{\mathrm{ed}}$ & $22.42 \pm 0.95^{\mathrm{b}}$ \\
C1 & $32.92 \pm 1.9^{\mathrm{f}}$ & $32.06 \pm 2.33^{\mathrm{d}}$ \\
C2 & $37.92 \pm 2.6^{\mathrm{e}}$ & $33.59 \pm 2.24^{\mathrm{c}}$ \\
& & \\
C3 & $45.83 \pm 1.4^{\mathrm{c}}$ & $33.97 \pm 0.33^{\mathrm{a}}$ \\
D1 & $42.08 \pm 1.8^{\mathrm{d}}$ & $40.1 \pm 1.1^{\mathrm{d}}$ \\
D2 & $56.25 \pm 1.25^{\mathrm{a}}$ & $48.13 \pm 1.03^{\mathrm{c}}$ \\
D3 & $52.07 \pm 1.9^{\mathrm{b}}$ & $41.19 \pm 0.75^{\mathrm{b}}$
\end{tabular}

Results are mean values of triplicate determinations, \pm standard deviation. Means in each column followed by different letters are significantly different $(\mathrm{P}<0.05)$ : small letters show statistical differences for data in column, respectively. 
Table 3. Thermal properties and Zeta potential of native and US treated MPC in $73.95 \mathrm{~W} / \mathrm{cm}^{2}$ for $12.5 \mathrm{~min}$

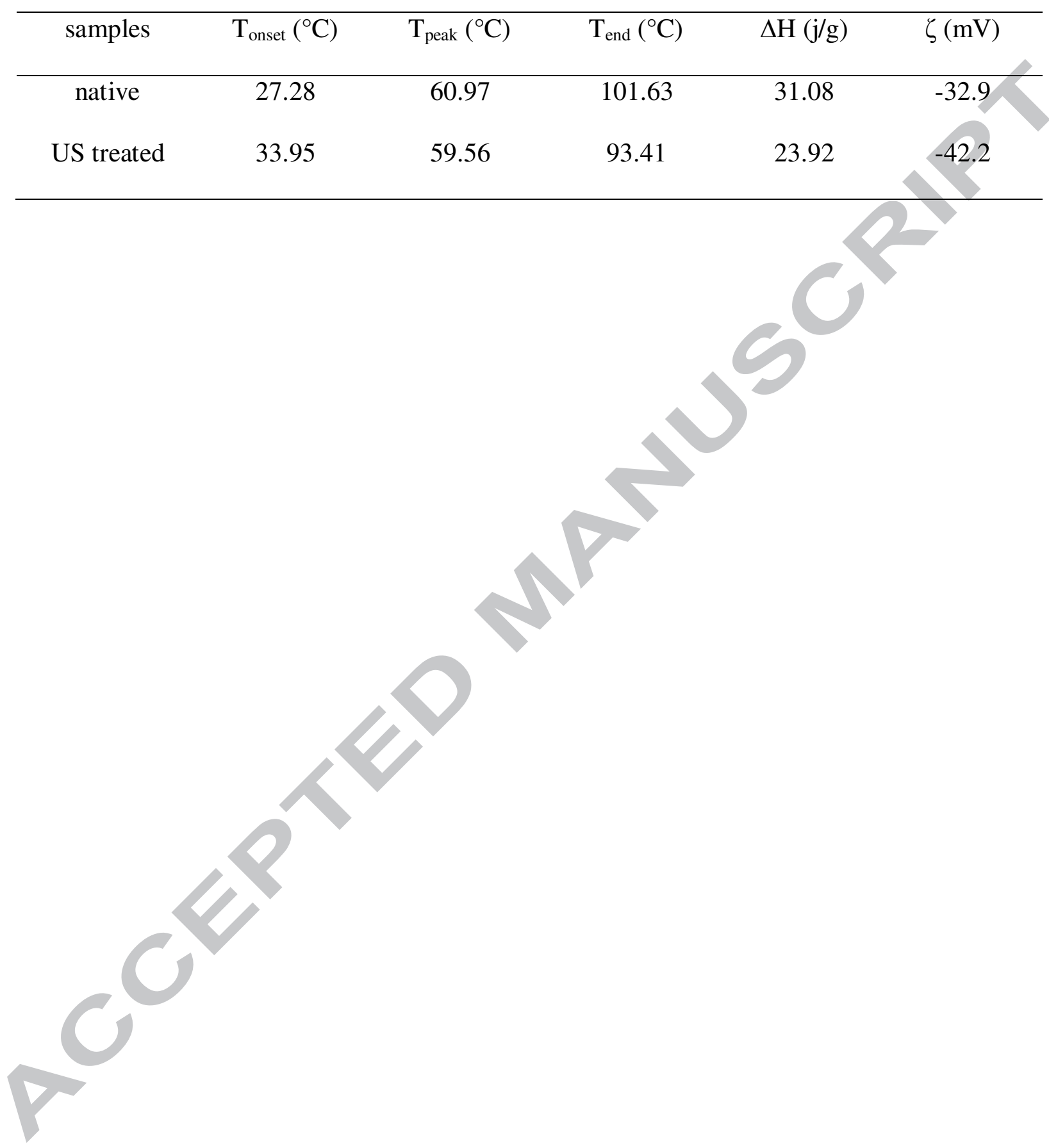


Figure 1

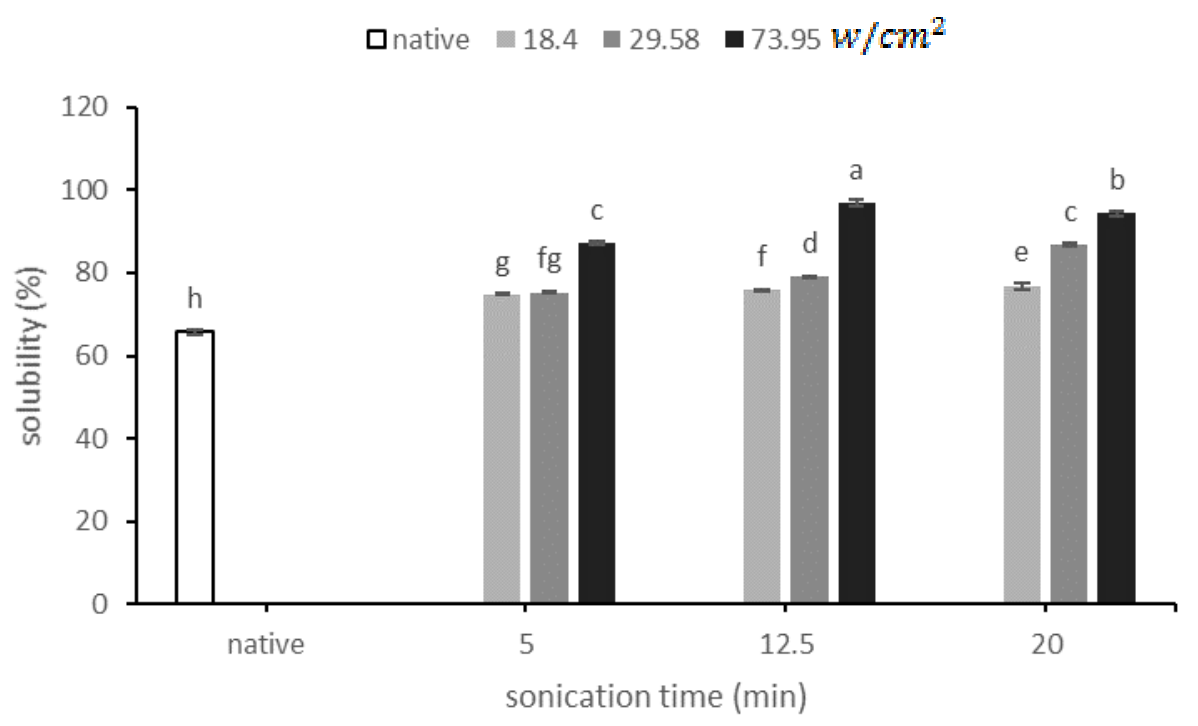


Figure 2

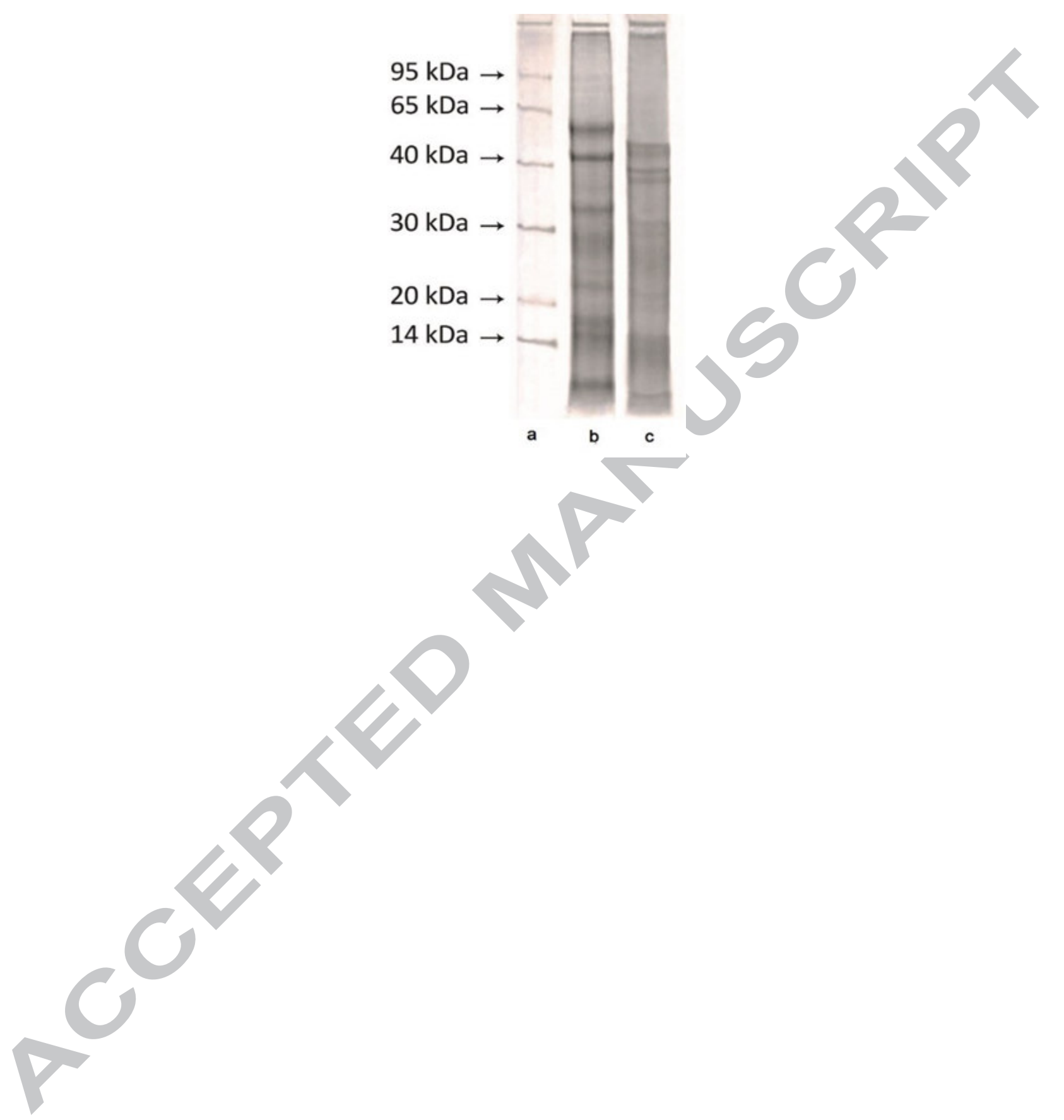


Figure 3

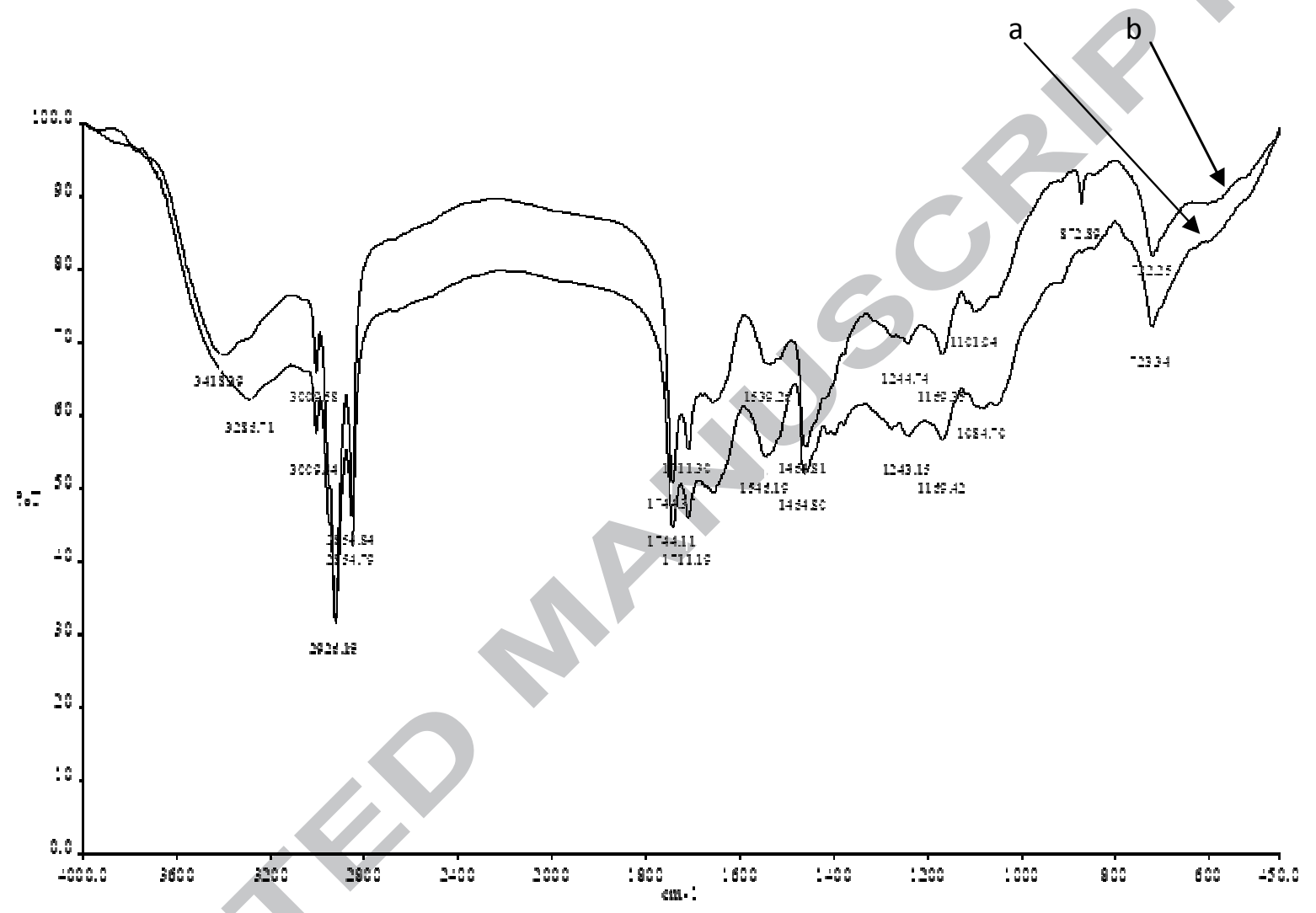


Fig. 1. Solubility of native and US treated MPC in $18.4,29.58$, and $73.95 \mathrm{~W} / \mathrm{cm}^{2}$ for $5,12.5$ and $20 \mathrm{~min}$.

Fig. 2. SDS-PAGE electrophoretic profiles of ladder (a), native (b) and US treated (c) MPC in $73.95 \mathrm{~W} / \mathrm{cm}^{2}$ for $12.5 \mathrm{~min}$.

Fig. 3. FTIR spectra of native (a) and US treated (b) MPC in $73.95 \mathrm{~W} / \mathrm{cm}^{2}$ for $12.5 \mathrm{~min}$. 


\section{Highlights}

1. High power ultrasound modified some functional properties of millet protein concentrate.

2. Structural changes in millet protein concentrate was shown upon ultrasound treatment.

3. Sonication performance declines at higher intensities for prolong times.

4. The best ultrasound treatment to modification of millet protein concentrate functional properties proposed. 